\section{The mammalian efflux pump inhibitor Valspodar (PSC833) improves susceptibility of MRSA to antibiotics}

\section{Abstract}

Aim: Inhibitors of mammalian efflux pumps are known to potentiate antibiotic susceptibility in bacteria by inhibiting bacterial efflux pumps as well. In this study the effect of 2nd generation mammalian efflux pump inhibitor valspodar (PSC833) on inhibition of efflux pumps in bacteria is tested.

Methods: Disc diffusion assay for several antimicrobial agents such as cefoxitine, oxacillin, gentamicin, ticarcillin-clavulanate norfloxacin and ofloxacin was performed in the presence and absence of PSC 833 in culture media of Gram positive and Gram negative bacteria and zones of inhibition were compared. Accumulation of the universal efflux pump substrate ethidium bromide in test organisms was measured in the presence and absence of PSC 833.

Results: PSC833 at concentrations starting from $62.5 \mu \mathrm{g} / \mathrm{ml}$ downwards till $3.12 \mu \mathrm{g} / \mathrm{ml}$ have significantly improved and restored the sensitivity of S.aureus and MRSA towards all tested antibiotics and resulted in highest accumulation of ethidium bromide within the cells, when compared to the other mammalian efflux inhibitors, verapamil and reserpine. However no effect was observed on the Gram negative $P$. aeruginosa and vancomycin resistant Enterococci (VRE).

Conclusions: The results of this study indicate that PSC 833 represents a good candidate for use in combination with examined antibiotics to restore their clinical efficacy.

Key words: valspodar (PSC833), Efflux pumps, MRSA, Oxacillin
Hanaa Hazim Dheyab1, Zuhair Muhi-eldeen ${ }^{2}$ and Suzanne M.A. Abdelmalek $^{1}$

1 Department of Pharmacology and biomedical sciences-Faculty of Pharmacy and medical sciences- Petra University Amman-Jordan

2 Department of Medicinal ChemistryFaculty of Pharmacy and Medical Sciences-Petra University-AmmanJordan

Corresponding author:

Suzanne M.A. Abdelmalek (SMA Abdelmalek)

”sabdelmalek@uop.edu.jo 


\section{Introduction}

Shortage of antibiotics in the treatment of multiple drug resistant (MDR) bacterial infections has necessitated the search for novel antibiotics or improvement of the existing ones. Improving the efficacy of the available antibiotics would certainly be a more reasonable alternative especially when these antibiotics have been extensively investigated and used by patients. One way to improve effectiveness would be by combining the antibiotic with a resistance mechanism inhibitor as in ampicillin/ sulbactam in which sulbactam acts as a B-lactamase inhibitor[1]. Efflux of antimicrobials by specific and nonspecific pumps is a multidrug resistance mechanism in bacteria. Inhibition of efflux renders the bacteria more susceptible to variable antimicrobials that happens to be substrates to these pumps. Thus the search for efflux inhibitors has been intriguing for scientists. Mammalian efflux pump inhibitors are used to overcome mammalian cells resistance to cancer drugs. Resemblance has been shown between the efflux pumps used by the mammalian cells and some efflux pumps in bacteria [2]. Clinically used mammalian efflux pump inhibitors (MEPI) are more encouraging to use when compared with non-mammalian inhibitors such as CCCP or reserpine that are known to have high toxicity in man [3]. Mullin et al (2004) demonstrated the usefulness of the mammalian efflux pump inhibitors biricodar (VX-710) and timcodar (VX-853) and tariquidarin in potentiating antibiotic susceptibility in Gram positive bacteria[4]. The effect was detected by either the increased intracellular concentration of labeled ciprofloxacin, or by the increased intracellular accumulation of the universal efflux pump substrate ethidium bromide after exposure of these bacteria to the efflux inhibitors [4]. Such results were promising for the development of new antibiotics combination. Antibiotic resistance in $S$. aureus involves several mechanisms: Methicillin resistance for example involves the synthesis of an alternative penicillin binding protein (PBP-2a) that is coded for by the mecA gene, aminoglycoside resistance is mediated by aminoglycoside modifying enzymes, ribosomal mutations, and active efflux. An array of efflux pumps were detected in S.aureus and methicillin resistant $S$. aureus, Both the efflux pumps NorB and NorC confer resistance to quinolones, such as ciprofloxacin, norfloxacin and sparfloxacin $[5,6]$. norA gene efflux proteins were thought to specifically efflux the norfloxacin, but subsequently was found to confer resistance to a number of antimicrobials, including chloramphenicol $[7,8]$. Of the natural efflux inhibitors that has been shown to have an inhibitory effect on NorA efflux pumps in S.aureus is reserpine [9]. Reserpine is a plant indole alkaloid that is known for its ability to inhibit activation of the efflux of cancer drugs outside the cells, however numerous side effects within its therapeutic range (0.1 to $0.25 \mathrm{mg}$ ) has been documented [10]. Verapamil on the other hand is a synthetic hypertension drug and a $1^{\text {st }}$ generation MEPI, this drug has been used as an inhibitor of the bacterial $p$-glycoprotein (p-gp) efflux pump [11]. Like verapamil, Valspodar (PSC833) a mammalian $p$-gp efflux pumps inhibitor that is clinically used to restore the activity of some drugs in drug-resistant tumor cells[12]. PSC833 however is a $2^{\text {nd }}$ generation $p$-gp pump inhibitor that is selective and less toxic than the first generation agents. PSC-833 is a non-immunosuppressive cyclosporine derivative that potently and specifically inhibits P-gp. In vitro experiments indicate that PSC833 interacts directly with $p$-gp with high affinity and probably interferes with the ATPase activity of p-gp. Studies in multidrug resistant tumour models confirm P-gp as the in vivo target of PSC-833 and demonstrate the ability of PSC-833 to reverse MDR leukaemias and solid tumours in mice [13]. To our knowledge PSC833 has not been investigated as a bacterial efflux pump inhibitor. The aim of this study is to evaluate the activity of PSC833 in bacteria through its ability to potentiate antibiotic activity and inhibiting efflux pumps. 


\section{Experimental}

\section{Compounds: antibiotics, chemicals and growth media}

Valspodar (PSC833) was obtained from Tocris $^{\circledR}$ (UK). A fresh stock solution of PSC833 was prepared by dissolving in dimethyl-sulfoxide (DMSO) to give a final concentration of $1 \mathrm{mg} / \mathrm{ml}$. Stock solutions of Verapamil and reserpine (Sigma ${ }^{\circledR}$ Aldrich) were prepared by dissolving the former in distilled water to give a final concentration of $5 \mathrm{mg} / \mathrm{ml}$, and the latter in dimethyl-sulfoxide( DMSO) to give a final concentration of $0.02 \mathrm{mg} / \mathrm{ml}$. Dilutions were prepared in sterile distilled water. The following antibiotic discs were obtained from Oxoid ${ }^{\circledR}$ (Germany), Oxacillin $(1 \mu \mathrm{g} / \mathrm{ml})$, norfloxacin $(10 \mu \mathrm{g} / \mathrm{ml})$, gentamicin $(10 \mu \mathrm{g} / \mathrm{ml})$, ofloxacin $(5 \mu \mathrm{g} / \mathrm{ml})$, ticarcillin clavulanic $\operatorname{acid}(85 \mu \mathrm{g} / \mathrm{ml})$, and cefoxitin $(30 \mu \mathrm{g} / \mathrm{ml})$. All chemicals and antibiotics were kept in cold, dark place (refrigerator). Mueller Hinton Agar (MHA) and broth (MHB) were obtained from Himedia (India).

\section{Bacterial strains}

The study was conducted on Staphylococcus aureus ATCC 6538, Pseudomonas aeruginosa ATCC 9027. Clinical strains: Methicillin resistant Staphylococcus aureus (MRSA), MDR Pseudomonas aeruginosa, and vancomycin resistant Enterococcus (VRE) obtained from king Hussein Cancer Center (KHCC). All bacterial strains were verified and identified at the source, and were maintained by sub culturing into fresh nutrient agar and Tryptic soy agar (Himedia, India) every 2 weeks. Cultures were also preserved in $10 \%$ glycerol at $-70^{\circ} \mathrm{C}$ until required for use.

\section{Determination of Minimal Effective Concentration (MEC) of PSC 833}

Varying concentrations of the PSC 833 starting from $250 \mu \mathrm{g} / \mathrm{ml}$ down to $3.12 \mu \mathrm{g} / \mathrm{ml}$ in $0.5 \mathrm{ml}$ of $\mathrm{MHB}$ were prepared. An aliquot of $50 \mu l$ of $S$. aureus or MRSA18-24hrs culture adjusted to contain $10^{5} \mathrm{CFU} /$ $\mathrm{ml}$ was added to all tubes[14]. Negative control tubes contained only $0.5 \mathrm{ml}$ of $\mathrm{MHB}$, and the test organism. Test tubes were incubated at $37^{\circ} \mathrm{C}$ for 15 and 30 min[14]. After 15 minutes sterile swabs were used to transfer from each tube to the surface of a fresh MHA plate. Inoculums were allowed to dry and antibiotic discs were applied on the plates. Plates were incubated at $37^{\circ} \mathrm{C}$ overnight. Diameter of zone of inhibition was measured in $\mathrm{mm}$. Experiment was repeated 3 times. Results are the average readings of three separate experiments according to the recommendation of CLSI [15].

\section{Kinetic study}

To identify the time required for PSC 833 to exert its best effect as measured by the diameter of the zone of inhibition of antibiotics, PSC 833 was added at a concentration of $62.5 \mu \mathrm{g} / \mathrm{ml}$ to bacterial culture containing $10^{5} \mathrm{CFU} / \mathrm{ml}$. Inoculums were cultured every 10 minutes on fresh MHA starting from 0 time which is upon the immediate addition of PSC833 to the media (nullifying the carry over effect) Antibiotic discs were applied. Bacterial controls in absence of PSC833 were also included. Plates were incubated at $37^{\circ} \mathrm{C}$ overnight. Diameter of the zones of inhibition were measured in $\mathrm{mm}$. Readings presented are the results of the average of three experiments.

\section{Detecting changes in MIC using E-Test}

E-Test (Oxoid) was performed according to manufacturer's instructions. Briefly, inoculums of an overnight culture of S.aureus and MRSA were adjusted to 0.1 O.D at $625 \mathrm{~nm}$ corresponding to $10^{6} \mathrm{CFU} / \mathrm{ml}$. An aliquot of PSC 833 was added to $1 \mathrm{ml}$ of MHB to give a concentration of $62.5 \mu \mathrm{g} / \mathrm{ml}$. An aliquot of the test culture (0.5 McFarland), was added to the mixture to get a final concentration of $10^{5} \mathrm{CFU} /$ $\mathrm{ml}$ tubes were then incubated for $30 \mathrm{~min}$. Bacterial culture from the tube was swabbed on the plate and allowed to dry. Oxacillin E-strip was applied. As specified by the manufacturer's instructions the 
detected MIC corresponded to the concentration of the antibiotic where growth of the test organism touched the sides of the strip

\section{Ethidium bromide accumulation assay}

Ethidium bromide efflux was determined as previously described [14]. Briefly S.aureus and MRSA were grown overnight in nutrient broth. Bacterial suspensions (O.D of 0.2 at $550 \mathrm{~nm}$ ) were prepared in uptake buffer $(110 \mathrm{mM} \mathrm{NaCl}, 7 \mathrm{mM} \mathrm{KCl}, 50 \mathrm{mM}$ $\mathrm{NH}_{4} \mathrm{Cl}, 0.4 \mathrm{mM} \mathrm{Na}_{2} \mathrm{HPO}_{4}, 52 \mathrm{mM}$ Tris base and $0.2 \%$ glucose, adjusted to $\mathrm{pH} 7.5$ with $\mathrm{HCl}$ ). Suspensions were exposed to $2 \mathrm{mg} / \mathrm{L}$ ethidium bromide in the presence of different efflux pump inhibitors (EPIs) for $30 \mathrm{~min}$ at $37^{\circ} \mathrm{C}$. The cells were pelleted down by centrifugation and resuspended in fresh buffer. Fluorescence was recorded every 5 minutes at an excitation wavelength of $530 \mathrm{~nm}$ and an emis- sion wavelength of $600 \mathrm{~nm}$ in a spectroflorometer (Promega Glomax®) for a period of 30 minutes starting immediately (0 time). Readings were compared to controls exposed to ethidium bromide for the same time period in the absence of any efflux inhibitor. Results plotted are the average of three readings on different sets of experiments.

\section{Results}

\section{Minimum effective concentration of PSC 833 (MEC)}

The exposure of both MRSA and S.aureus to descending concentrations of PSC833 resulted in a significant increase in the diameter of zone of inhibition of all antibiotics used (Table 1). However comparing the percentage increase in the diameter

Table 1. Determination of the minimal effective concentration of valspodar (PSC338) as a function of diameter of zone of inhibition in $\mathrm{mm}$.

\begin{tabular}{|c|c|c|c|c|c|c|c|c|c|c|c|c|c|c|}
\hline \multirow{3}{*}{ Antibiotic } & \multicolumn{4}{|c|}{ Bacteria } & \multicolumn{10}{|c|}{ Diameter of Zone of inhibition $\mathrm{mm}$ (\% increase in Zone of inhibition } \\
\hline & & \multirow[t]{2}{*}{ R. } & \multirow[t]{2}{*}{ I* } & \multirow[t]{2}{*}{ S } & \multirow[t]{2}{*}{ Control } & \multicolumn{9}{|c|}{ PSC338 concentration $(\mu \mathrm{g} / \mathrm{ml})$} \\
\hline & & & & & & 250 & 125 & 62.5 & 50 & 31.25 & 25 & 12.5 & 6.25 & 3.12 \\
\hline \multirow[t]{2}{*}{ Gentamycin } & S. aureus & $\leq 14$ & $15-17$ & $\geq 18$ & 20 & $\begin{array}{c}32 \\
(60)\end{array}$ & $\begin{array}{c}31 \\
(55)\end{array}$ & $\begin{array}{c}31 \\
(55)\end{array}$ & $\begin{array}{c}30 \\
(50)\end{array}$ & $\begin{array}{c}30 \\
(50)\end{array}$ & $\begin{array}{c}28 \\
(40)\end{array}$ & $\begin{array}{c}26 \\
(30)\end{array}$ & $\begin{array}{c}18 \\
(-10)\end{array}$ & $\begin{array}{c}13 \\
(-35)\end{array}$ \\
\hline & MRSA & & & & 13 & $\begin{array}{c}30 \\
(130)\end{array}$ & $\begin{array}{c}30 \\
(130)\end{array}$ & $\begin{array}{c}29 \\
(123)\end{array}$ & $\begin{array}{c}26 \\
(100)\end{array}$ & $\begin{array}{c}15 \\
(15)\end{array}$ & $\begin{array}{c}25 \\
(92)\end{array}$ & $\begin{array}{c}24 \\
(84)\end{array}$ & $\begin{array}{c}21 \\
(61)\end{array}$ & $\begin{array}{c}28 \\
(115)\end{array}$ \\
\hline \multirow[t]{2}{*}{ Oxacillin } & S. aureus & $\leq 12$ & $13-14$ & $\geq 15$ & 21 & $\begin{array}{c}30 \\
(54)\end{array}$ & $\begin{array}{c}29 \\
(52)\end{array}$ & $\begin{array}{c}28 \\
(51)\end{array}$ & $\begin{array}{c}58 \\
(333)\end{array}$ & $\begin{array}{c}26 \\
(100)\end{array}$ & $\begin{array}{c}50 \\
(233)\end{array}$ & $\begin{array}{c}39 \\
(85)\end{array}$ & $\begin{array}{c}39 \\
(85)\end{array}$ & $\begin{array}{c}40 \\
(90)\end{array}$ \\
\hline & MRSA & & & & 6 & $\begin{array}{c}16 \\
(30)\end{array}$ & $\begin{array}{c}15 \\
(28)\end{array}$ & $\begin{array}{c}14 \\
(27)\end{array}$ & $\begin{array}{c}26 \\
(22)\end{array}$ & $\begin{array}{c}12 \\
(26)\end{array}$ & $\begin{array}{c}20 \\
(21)\end{array}$ & $\begin{array}{c}20 \\
(233)\end{array}$ & $\begin{array}{c}19 \\
(216)\end{array}$ & $\begin{array}{c}20 \\
(233)\end{array}$ \\
\hline \multirow[t]{2}{*}{ Ticar/clav } & S. aureus & $\leq 10$ & $11-12$ & $\leq 13$ & 30 & $\begin{array}{c}54 \\
(80)\end{array}$ & $\begin{array}{c}52 \\
(73)\end{array}$ & $\begin{array}{c}51 \\
(70)\end{array}$ & $\begin{array}{c}47 \\
(56)\end{array}$ & $\begin{array}{c}50 \\
(66)\end{array}$ & $\begin{array}{c}41 \\
(36)\end{array}$ & $\begin{array}{c}42 \\
(40)\end{array}$ & $\begin{array}{c}43 \\
(43)\end{array}$ & $\begin{array}{c}45 \\
(50)\end{array}$ \\
\hline & MRSA & & & & 6 & $\begin{array}{c}30 \\
(400)\end{array}$ & $\begin{array}{c}28 \\
(366)\end{array}$ & $\begin{array}{c}27 \\
(350)\end{array}$ & $\begin{array}{c}22 \\
(266)\end{array}$ & $\begin{array}{c}26 \\
(333)\end{array}$ & $\begin{array}{c}21 \\
(250)\end{array}$ & $\begin{array}{c}20 \\
(233)\end{array}$ & $\begin{array}{c}19 \\
(216)\end{array}$ & $\begin{array}{c}20 \\
(233)\end{array}$ \\
\hline \multirow[t]{2}{*}{ ofloxacin } & S. aureus & $\leq 12$ & $13-16$ & $\geq 17$ & 28 & $\begin{array}{c}62 \\
(121)\end{array}$ & $\begin{array}{c}62 \\
(121)\end{array}$ & $\begin{array}{c}62 \\
(121)\end{array}$ & $\begin{array}{c}66 \\
(135)\end{array}$ & $\begin{array}{c}55 \\
(96)\end{array}$ & $\begin{array}{c}60 \\
(114)\end{array}$ & $\begin{array}{c}45 \\
(60)\end{array}$ & $\begin{array}{c}43 \\
(53)\end{array}$ & $\begin{array}{l}28 \\
(0)\end{array}$ \\
\hline & MRSA & & & & 13 & $\begin{array}{c}30 \\
(130)\end{array}$ & $\begin{array}{c}30 \\
(130)\end{array}$ & $\begin{array}{c}30 \\
(130)\end{array}$ & $\begin{array}{c}31 \\
(138)\end{array}$ & $\begin{array}{c}26 \\
(100)\end{array}$ & $\begin{array}{c}30 \\
(130)\end{array}$ & $\begin{array}{c}30 \\
(130)\end{array}$ & $\begin{array}{c}28 \\
(115)\end{array}$ & $\begin{array}{c}10 \\
(-23)\end{array}$ \\
\hline \multirow[t]{2}{*}{ norfloxacin } & S. aureus & $\leq 15$ & $13-15$ & $\geq 16$ & 28 & $\begin{array}{c}56 \\
(100)\end{array}$ & $\begin{array}{c}56 \\
(100)\end{array}$ & $\begin{array}{c}52 \\
(85)\end{array}$ & $\begin{array}{c}66 \\
(135)\end{array}$ & $\begin{array}{c}49 \\
(75)\end{array}$ & $\begin{array}{c}54 \\
(92)\end{array}$ & $\begin{array}{c}54 \\
(92)\end{array}$ & $\begin{array}{c}47 \\
(67)\end{array}$ & $\begin{array}{c}36 \\
(28)\end{array}$ \\
\hline & MRSA & & & & 13 & $\begin{array}{c}30 \\
(130)\end{array}$ & $\begin{array}{c}30 \\
(130)\end{array}$ & $\begin{array}{c}28 \\
(115)\end{array}$ & $\begin{array}{c}32 \\
(146)\end{array}$ & $\begin{array}{c}24 \\
(84)\end{array}$ & $\begin{array}{c}32 \\
(146)\end{array}$ & $\begin{array}{c}33 \\
(153)\end{array}$ & $\begin{array}{c}30 \\
(130)\end{array}$ & $\begin{array}{c}20 \\
(53)\end{array}$ \\
\hline \multirow[t]{2}{*}{ cefoxitine } & S. aureus & $\leq 14$ & $18-19$ & $\geq 20$ & 28 & $\begin{array}{c}55 \\
(96)\end{array}$ & $\begin{array}{c}55 \\
(96)\end{array}$ & $\begin{array}{c}56 \\
(100)\end{array}$ & $\begin{array}{c}53 \\
(89)\end{array}$ & $\begin{array}{c}47 \\
(67)\end{array}$ & $\begin{array}{c}50 \\
(78)\end{array}$ & $\begin{array}{c}46 \\
(64)\end{array}$ & $\begin{array}{c}42 \\
(50)\end{array}$ & $\begin{array}{c}50 \\
(78)\end{array}$ \\
\hline & MRSA & & & & 10 & $\begin{array}{c}27 \\
(170)\end{array}$ & $\begin{array}{c}27 \\
(170)\end{array}$ & $\begin{array}{c}27 \\
(170)\end{array}$ & $\begin{array}{c}30 \\
(200)\end{array}$ & $\begin{array}{c}21 \\
(110)\end{array}$ & $\begin{array}{c}29 \\
(190)\end{array}$ & $\begin{array}{c}24 \\
(140)\end{array}$ & $\begin{array}{c}22 \\
(120)\end{array}$ & $\begin{array}{c}29 \\
(190)\end{array}$ \\
\hline
\end{tabular}

${ }^{*}$ CLSI breakpoints for antibiotics: R: resistant, I: intermediate sensitivity, S: sensitive. 
Table 2. Effect of exposure time on valspodar (PSC 833) activity.

\begin{tabular}{|c|c|c|c|c|c|c|c|c|}
\hline \multirow[t]{3}{*}{ Antibiotic } & \multirow[t]{3}{*}{ Bacteria } & Control & \multicolumn{6}{|c|}{ Diameter of Zone of inhibition $\mathrm{mm}$} \\
\hline & & \multicolumn{7}{|c|}{ Time in minutes } \\
\hline & & 0 & 10 & 20 & 30 & 40 & 50 & 60 \\
\hline \multirow[t]{2}{*}{ Gentamycin } & S.aureus & 15 & 38 & 30.3 & 30.3 & 30.3 & 36 & 34.6 \\
\hline & MRSA & 10 & 35.6 & 30.3 & 30 & 30 & 34 & 33.3 \\
\hline \multirow[t]{2}{*}{ Oxacillin } & S.aureus & 15 & 30 & 30.3 & 30 & 30 & 30 & 30 \\
\hline & MRSA & 6 & 18 & 16.3 & 18.6 & 14.6 & 22.6 & 22.6 \\
\hline \multirow[t]{2}{*}{ Ticarcillin } & S.aureus & 25 & 30 & 40 & 30 & 24.3 & 29 & 40 \\
\hline & MRSA & 6 & 16 & 18.3 & 19 & 15 & 20 & 20.6 \\
\hline \multirow[t]{2}{*}{ Ofloxacin } & S.aureus & 15 & 32 & 32 & 31.6 & 30.33 & 32 & 30.3 \\
\hline & MRSA & 13 & 32 & 31.6 & 31.6 & 31.3 & 30 & 30 \\
\hline \multirow[t]{2}{*}{ Norfloxacin } & S.aureus & 15 & 35 & 34.3 & 33.3 & 30.3 & 30 & 34.6 \\
\hline & MRSA & 13 & 30 & 30 & 30.3 & 29.6 & 30 & 31.3 \\
\hline
\end{tabular}

of the zone of inhibition for each antibiotic at each PSC833 concentration used relative to the concentration of the antibiotic on the disc have led us to conclude that the MEC was variable according to the antibiotic but a concentration of $50 \mathrm{ug} / \mathrm{ml}$ was found potentiating for the activity of all antibiotics.

\section{Time dependent effect of valspodar (PSC}

\section{3) on MRSA and S. aureus antibiotic susceptibility.}

A relatively high concentration of PSC833 (62.5 $\mu \mathrm{g} / \mathrm{ml}$ ) was chosen to maximize the chance of observing an effect in combination with antibiotics against isolates with multiple resistance mechanisms. Kinetic studies using disc diffusion technique showed that after 10 minutes exposure there was a significant $\geq 2$ fold increase $(P<0.05$ (Mann Whitney test/SPSS)) in the zone of inhibition of all antibiotics except for ticarcillin. Susceptibility to ticarcillin improved after 20 min by 1.6 fold for S.aureus and almost 3 folds on MRSA (Table 2). Immediate contact with PSC833 (0 time) didn't show significant increase in the zone of inhibition (Table 2) indicating that exposure time is required.

\section{Changes in minimal inhibitory concentration of Oxacillin as detected by E test}

Oxacillin E-test was performed to detect the changes in MIC in both MRSA and S.aureus. Exposure of S.aureus and MRSA for 30 min. significantly reduced the MIC of Oxacillin (Table 3).

\section{Comparing the effect of PSC833 to other MEPIs on S.aureus and MRSA.}

Effect of PSC 833 on improving antibiotic sensitivity towards S.aureus and MRSA was compared to two known mammalian efflux pump inhibitors Verapamil and reserpine. PSC833 effect on improv-

Table 3. Changes in MIC of Oxacillin in both S. aureus and MRSA upon exposure to valspodar (PSC 833)

\begin{tabular}{|c|c|c|c|}
\hline \multirow{2}{*}{$\begin{array}{c}\text { Bacterial } \\
\text { culture }\end{array}$} & \multicolumn{2}{|c|}{ MIC $(\mu \mathrm{g} / \mathrm{ml})$} & \% decrease in MIC \\
\cline { 2 - 4 } S. aureus & control & PSC 833 & \\
\hline MRSA & 0.06 & 0.015 & $75 \%$ \\
\hline
\end{tabular}


Table 4. Comparison between effect of valspodar (PSC338) and other efflux inhibitors on S. aureus and MRSA sensitivities to antibiotics.

\begin{tabular}{|c|c|c|c|c|c|}
\hline \multirow{2}{*}{ Antibiotic } & \multirow{2}{*}{ Bacterial strain } & \multicolumn{4}{|c|}{ Zone of inhibition (mm) } \\
\hline & & Control* & valspodar $62.5 \mu \mathrm{g} / \mathrm{ml}$ & verapamil $200 \mu \mathrm{g} / \mathrm{ml}$ & Reserpine $2 \mu \mathrm{g} / \mathrm{ml}$ \\
\hline \multirow[t]{2}{*}{ Gentamycin } & S.aureus & 20 & 34.6 & 34 & 27.3 \\
\hline & MRSA & 13 & 32 & 36 & 27.3 \\
\hline \multirow[t]{2}{*}{ Oxacillin } & S.aureus & 21 & 30 & 30.3 & 15 \\
\hline & MRSA & 6 & 26 & 29 & 6 \\
\hline \multirow[t]{2}{*}{ Ticarcillin/clav } & S.aureus & 30 & 38 & 38 & 25 \\
\hline & MRSA & 6 & 31 & 27 & 6 \\
\hline \multirow[t]{2}{*}{ Ofloxacin } & S.aureus & 28 & 30 & 30 & 21 \\
\hline & MRSA & 13 & 30 & 28 & 21 \\
\hline \multirow[t]{2}{*}{ Norfloxacin } & S.aureus & 28 & 31 & 31 & 26.3 \\
\hline & MRSA & 13 & 30.6 & 32.6 & 26.3 \\
\hline \multirow[t]{2}{*}{ Cefoxitine } & S.aureus & 28 & 35.6 & 35.6 & 20 \\
\hline & MRSA & 10 & 28.6 & 32 & 10 \\
\hline
\end{tabular}

${ }^{*}$ Controls are MEPI unexposed cells.

ing antibiotic susceptibility as detected by increase in diameter of zone of inhibition was significantly $(p<0.05)$ superior to that of reserpine on both $S$. aureus and MRSA. However incomparable effect was observed between both Verapamil and PSC833 (Table 4). Reserpine on the other hand potentiated the activity of the floroquinolones (ofloxacin, norfloxacin) and gentamycin in MRSA.

\section{Other bacterial strains}

No observed effect of PSC 833 under the same conditions in both MDR $P$. aeruginosa, and vancomycin resistant enterococci and within the same range of antibiotics used.

\section{Ethidium bromide accumulation assay}

The ability of PSC833 to inhibit the efflux of ethidium bromide was evaluated through measuring level of accumulation of this substrate within S.aureus and MRSA in the presence and absence of PSC833. The accumulation of EtBr in cells exposed to PSC833 for 30 min was significantly higher $(P<0.05)$ than accumulation in cells not exposed to the MEPI
(Figure 1A, 1B). The same result was observed with verapamil and the combination of both verapamil and PSC833. Reserpine on the other hand was significantly less efficient in inhibiting efflux of EtBr in comparison to PSC833 ( $p<0.05$ ) in both $S$. aureus and MRSA. In fact the exposure of $\mathrm{S}$. aureus to reserpine resulted in almost the same accumulation levels to that of controls (Figure 1B). Over a period of 30 minutes there were no observed loss of fluorescence in the MEPI treated cells (Figure 2A, 2B) .

\section{Discussion}

Multi drug resistance in bacteria is identified by either a reduced diameter of zone of inhibition in the disc diffusion assays or increased MIC towards a group of unrelated antibiotics. In this study a significant increase was observed in the diameter of zone of inhibition of the used antibiotics upon exposure of test strains to PSC833.

Although it is well established that B-lactamresistance in $S$. aureus is mediated by $B$-lactamase 


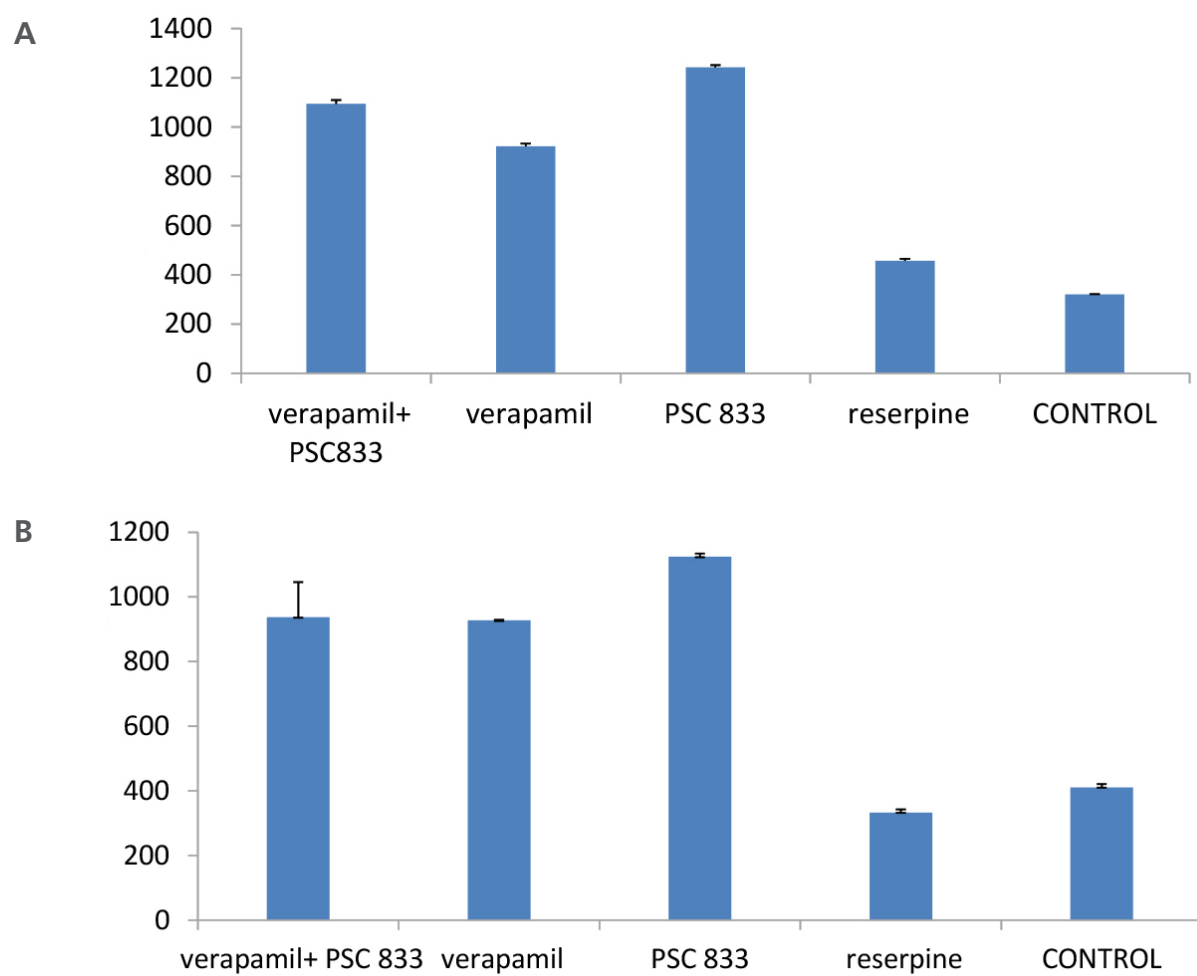

Figure 1. Accumulation of EtBr in S. aureus (A) and MRSA (B) after 30 minutes exposure to PSC833 (62.5 $\mu \mathrm{g} / \mathrm{ml})$ or verapamil $(200 \mu \mathrm{g} / \mathrm{ml})$ or Reserpine at $(2 \mu \mathrm{g} / \mathrm{ml})$

A
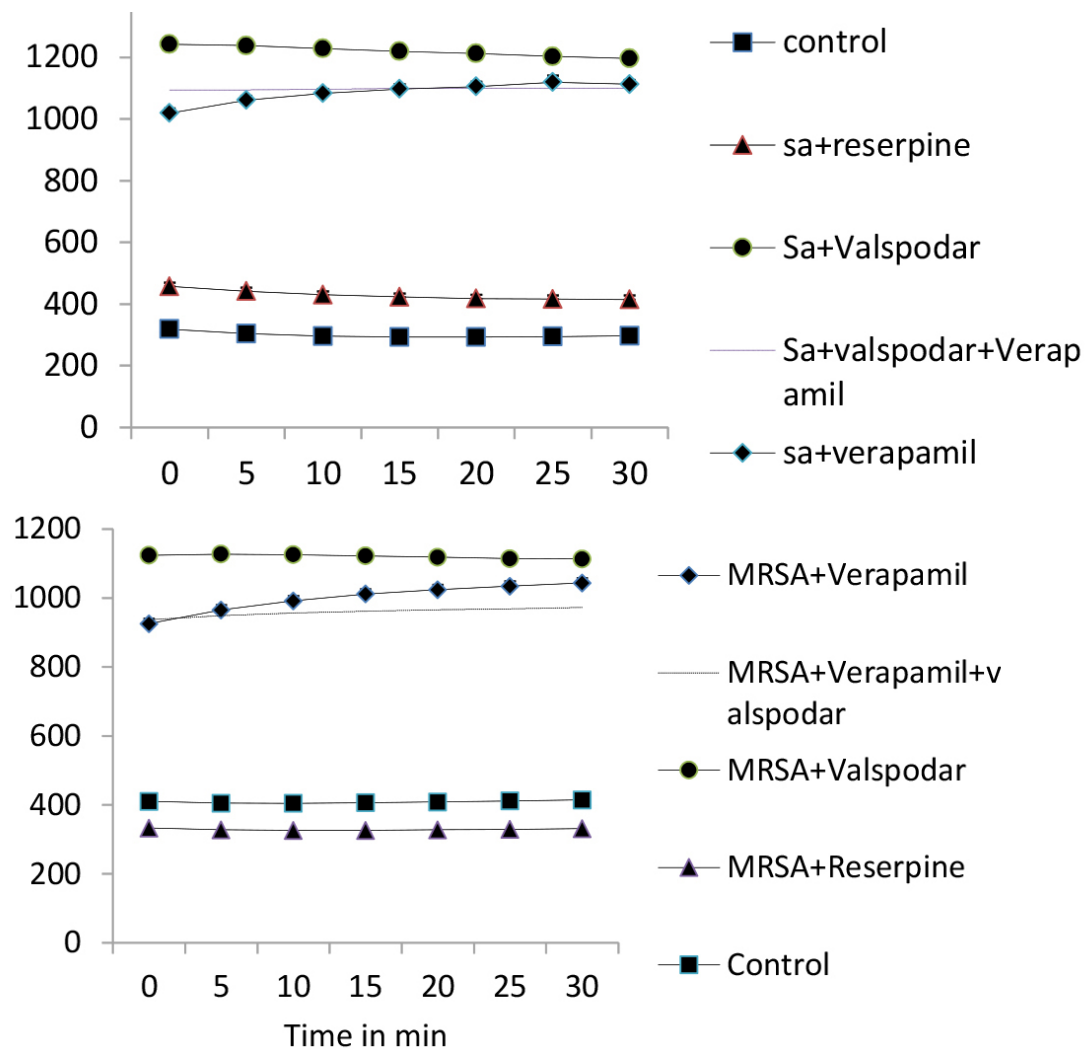

Figure 2. Accumulation of EtBr in S. aureus (A) and MRSA (B) after exposure to MEPls over a period of 30 min. S. aureus cells were loaded with $\operatorname{EtBr}(2 \mathrm{mg} / \mathrm{L})$ in the presence of valspodar (PSC833) $(62.5 \mu \mathrm{g} / \mathrm{ml})$ or verapamil $(200 \mu \mathrm{g} / \mathrm{ml})$ or Reserpine at $(2 \mu \mathrm{g} / \mathrm{ml})$. 
and/or the expression of penicillin-binding protein 2a (PBP 2a) [16], the exposure of S.aureus and the clinical multi drug resistant MRSA strain to the MEPI (PSC833) improved their susceptibility to all B-lactams used with the complete restoration of activity for both oxacillin and cefoxitin. However this effect was relatively less prominent on floroquinolones activity on MRSA. Improvement of the activity of the versatile antibiotics used in this study after exposure to PSC833, indicates that these antibiotics could be substrates of a nonspecific efflux pump or that PSC833 is affecting more than one efflux pump. Cefoxitin, gentamicin and floroquinolones are known to be substrates of different efflux pumps such as Lmr and NorA in S.aureus strains $[14,17]$. Reserpine is known to be an inhibitor of NorA pump in S.aureus and MRSA [14]. Reserpine significantly had better influence in improving susceptibility of MRSA towards floroquinolones compared to its effect on susceptibility towards ticarcillin and oxacillin. A comparison between reserpine and PSC833 (that potentiated the activity of all types of antibiotics) implies that the PSC 833 could actually be inhibiting more than one specific pump.

Efflux pump inhibitors are known to have variable effective concentrations depending on type of antibiotic and on the microbial strain [14,18 ], which explains the activity of PSC833 on S. aureus strains and not on other bacteria used in this study, moreover, MRSA strain was more affected by PSC833 than S. aureus. Clinical strains are known to express many different resistance mechanisms including multiple target-based mutations in addition to efflux mutations [4]. Thus novel, induced or overexpressed pumps in MRSA could be involved.

Minimal effective concentrations of PSC833 varied between various antibiotics used and with some antibiotics the MEC that resulted in $\geq$ two fold increase in diameter of zone of inhibition was as low as $3.12 \mu \mathrm{g} / \mathrm{ml}$. allowing concentration flexibility in combination with antibiotic, thus avoiding side effects (Table 1).
Ethidium bromide is a known universal substrate for efflux pumps in bacteria[19]. This substrate when inside the cell intercalates with cellular DNA resulting in a detectable fluorescence if subjected to UV light. The increased accumulation of EtBr after 30 minutes exposure to PSC833 compared to that of the PSC833 unexposed cells (Figure 1A, 1B) substantiates the role of efflux pumps in resistance in these strains.

Recently Costa et al (2013) reviewed the efflux mechanisms of resistance in S. aureus and MRSA[20]. The authors have shown that most of the pumps in these organisms are energized by $\mathrm{H}^{+}$: drug antiport mechanism and that none of the reported efflux pumps in S. aureus or MRSA have B-lactam antibiotics in their substrate collection. However, TruongBolduc Q. (2007) reported the presence of an ABC transporter designated AbcA pump in MRSA that extrudes hydrophobic B-lactams such as nafcillin, penicillin, methicillin and cefotaxime [21], which explains involvement of efflux pumps in B-lactam resistance in S. aureus and MRSA. Such pump or a similar one could explain the observed results in this study. Alternatively, PSC833 could simply be binding to the transporter protein thus inhibiting drug transport rather than dissipating energy [14].

Comparative studies between PSC833 and other MEPI using the same experiments and the same conditions have shown similarity in effect between PSC833 and verapamil (Table 3), however, reserpine was less effective in potentiating antibiotic susceptibility other than the quinolones (ofloxacin and norfloxacin) and gentamicin. In addition to that, reserpine had no effect at all on the activity of B-lactams on MRSA (Table 3) this effect was substantiated by its diminished ability to influence accumulation of EtBr (Figure 1, 2). The inhibition of efflux pumps by reserpine is dependent on the type and nature of the substrate [14]. Pumps like NorA, QacA, NorM of MRSA are known to be inhibited by reserpine but not by verapamil [20]. Consequently another pump must be involved in the resistance 
to B-lactams here and a suitable candidate seems to be the previously suggested AbcA pump. AbcA pump is a member of group A family of ATP-dependent transporters which are energized by ATP hydrolysis. MgrA is a regulator protein that is a direct activator of the abcA efflux gene in MRSA. The deactivation of this regulator protein will result in the inhibition of this pump resulting in improved susceptibility towards its substrates (quinolones and B-lactams). Moreover the effect of these two MEPIs (PSC833 and verapamil) could be simply through dissipating the energy of the AbcA pump rendering it inactive [21].

This explanation suits well the effect of the latter two MEPIs since both are P-glycoprotein pump inhibitors [22] and exposure of the study strains to both of them resulted in a significant difference in the diameter of zones of inhibition to the six antibiotics (Table 3) and observed difference between the level of fluorescence detected after exposure to both inhibitors in MRSA (Figure 1). In fact these results suggest the possibility of a similar target for both Verapamil and PSC833.

$A B C$ transporters are a conserved group of proteins that confer not only multidrug resistance in bacteria but also resistance to anticancer agents in mammalian cells[23]. PSC833 is therapeutically used at a dose of $(10 \mathrm{mg} / \mathrm{ml} / \mathrm{kg})$. It has been evaluated for safety in the clinic and in combination with chemotherapeutic agents for cancer therapies [12].We have shown that it can act as a bacterial EPI at a concentration of 62.5 $\mu \mathrm{g} / \mathrm{ml}$ and less. One disadvantage of PSC833 is being a substrate of the CYP 3A4 cytochrome, which use, might result in modified bioavailability and dose of other drugs [12]. This disadvantage necessitates more in vivo studies to assure its usefulness and safety in combination with antibiotics.

This study showed that PSC833 restored/enhanced the activities of several antibiotics on methicillin-resistant $S$. aureus, suggesting the importance of PSC833 as a bacterial efflux inhibitor in vitro. To validate the use of PSC833 in combination with ex- isting antibiotics in treatment of multidrug resistant Gram positive bacteria and use in human, synergism studies with different antibiotics as well as in vivo studies should follow to insure its effectiveness and safety.

\section{Conclusions}

The findings in this study indicate that valspodar (PSC833) can act as a Gram-positive bacterial efflux pump inhibitor at a minimum effective concentration of $62.5 \mu \mathrm{g} / \mathrm{ml}$ and less depending on type of antibiotic. Effect of PSC833 on antibiotic susceptibility was concentration dependent, but not time dependent. Our findings showed similarity with those of another $1^{\text {st }}$ generation MEPI (verapamil), and were significantly $(p<0.05)$ better than those of the natural MEPI (reserpine).

\section{Acknowledgment}

The authors wish to thank the Deanship of Scientific Research at Petra University for funding this research.

\section{References}

1. Drawz SM, Bonomo RA. Three decades of $\beta$-lactamase inhibitors. Clin. Microbiol Rev 2010; 23(1): 160-201.

2. Lomovskaya O, Warren MS, Lee A, Galazzo J, Fronko R, Lee $M$, "et al." Identification and characterization of inhibitors of multidrug resistance efflux pumps in Pseudomonas aeruginosa: novel agents for combination therapy. Antimicrob Agents Chemother 2001; 45(1): 105-16.

3. Neyfakh AA, Bidnenko VE, Chen LB. Efflux-mediated multidrug resistance in Bacillus subtilis: similarities and dissimilarities with the mammalian system. PNAS 1991; 88(11): 4781-5.

4. Mullin S, Mani N, Grossman TH. Inhibition of antibiotic efflux in bacteria by the novel multidrug resistance inhibitors biricodar (VX-710) and timcodar (VX-853). Antimicrob Agents Chemother 2004; 48(11): 4171-6.

5. Ding Y, Onodera Y, Lee JC, Hooper DC. NorB, an efflux pump in Staphylococcus aureus strain MW2, contributes to bacterial 
fitness in abscesses. J Bacteriol 2008; 190(21): 7123-9.6.

6. Hirai K, Aoyama H, Suzue S, Irikura T, lyobe S, Mitsuhashi S. Isolation and characterization of norfloxacin-resistant mutants of Escherichia coli K-12. Antimicrob Agents Chemother 1986; 30(2): 248-53.

7. Hassan KA, Skurray RA, Brown MH. Active export proteins mediating drug resistance in staphylococci. JMMB 2007; 12(34): 180-96.

8. Brown MH, Skurray RA. Staphylococcal multidrug efflux protein QacA. JMMB 2001; 3(2): 163-70.

9. Schmitz FJ, Fluit AC, Lückefahr M, Engler B, Hofmann B, Verhoef J, "et al.". The effect of reserpine, an inhibitor of multidrug efflux pumps, on the in-vitro activities of ciprofloxacin, sparfloxacin and moxifloxacin against clinical isolates of Staphylococcus aureus. Antimicrob Agents Chemother 1998; 42(6): 807-10.

10. Baumeister AA, Hawkins MF, Uzelac SM. The myth of reserpineinduced depression: role in the historical development of the monoamine hypothesis. J_Hist_Neurosci 2003; 12(2): 207-20.

11. Wilimowska J, Piekoszewski W, Krzyanowska-Kierepka E, Florek E. Monitoring of verapamil enantiomers concentration in overdose. Clin Toxicol 2006; 44(2): 169-71.

12. Thomas H, Coley HM. Overcoming multidrug resistance in cancer: an update on the clinical strategy of inhibiting p-glycoprotein. Cancer control 2003; 10(2): 159-

13. Amaral L, Spengler G, Martins A, Armada A, Handzlik J, KiecKononowicz K, Molnar J. Inhibitors of bacterial efflux pumps that also inhibit efflux pumps of cancer cells. Anticancer Res 2012; 32(7): 2947-57.

14. Kumar A, Khan IA, Koul S, Koul JL, Taneja SC, Ali I, "et al." Novel structural analogues of piperine as inhibitors of the NorA efflux pump of Staphylococcus aureus. Antimicrob Agents Chemother 2008; 61(6): 1270-6.

15. Wikler MA. Performance standards for antimicrobial susceptibility testing: Sixteenth informational supplement. Clinical and Laboratory Standards Institute(CLSI) ; 2006.

16. Fuda CC, Fisher JF, Mobashery S. $\beta$-Lactam resistance in Staphylococcus aureus: the adaptive resistance of a plastic genome. Cellular and molecular life sciences. 2005; 62(22): 2617-33.

17. Floyd JL, Smith KP, Kumar SH, Floyd JT, Varela MF. LmrS is a multidrug efflux pump of the major facilitator superfamily from Staphylococcus aureus. Antimicrob Agents Chemother 2010; 54(12): 5406-12.

18. Chevalier J, Mahamoud A, Baitiche M, Adam E, Viveiros M, Smarandache A, "et al." Quinazoline derivatives are efficient chemosensitizers of antibiotic activity in Enterobacter aerogenes, Klebsiella pneumoniae and Pseudomonas aeruginosa resistant strains. Int J Antimicrob Agents 2010; 36(2): 164-8.

19. Giraud E, Cloeckaert A, Kerboeuf D, Chaslus-Dancla E. Evidence for active efflux as the primary mechanism of resistance to ciprofloxacin in Salmonella enterica serovar Typhimurium. Antimicrob Agents Chemother 2000; 44(5): 1223-8.
20. Costa SS, Viveiros M, Amaral L, Couto I. Multidrug efflux pumps in Staphylococcus aureus: an update. TOMICROJ 2013; 7(1).

21. Garvey MI, Piddock LJ. The efflux pump inhibitor reserpine selects multidrug-resistant Streptococcus pneumoniae strains that overexpress the $A B C$ transporters Pat $A$ and PatB. Antimicrob Agents Chemother 2008; 52(5): 1677-85

22. Truong-Bolduc QC, Hooper DC. The transcriptional regulators NorG and MgrA modulate resistance to both quinolones and $\beta$-lactams in Staphylococcus aureus. J Bacteriol 2007; 189(8): 2996-3005.

23. Ughachukwu PO, Unekwe PC. Efflux Pump. Mediated Resistance in Chemotherapy. Ann Med Health Sci Res 2012; 2(2): 191-8.

\section{Comment on this article:}

( $)$ in $\mathbf{S}$

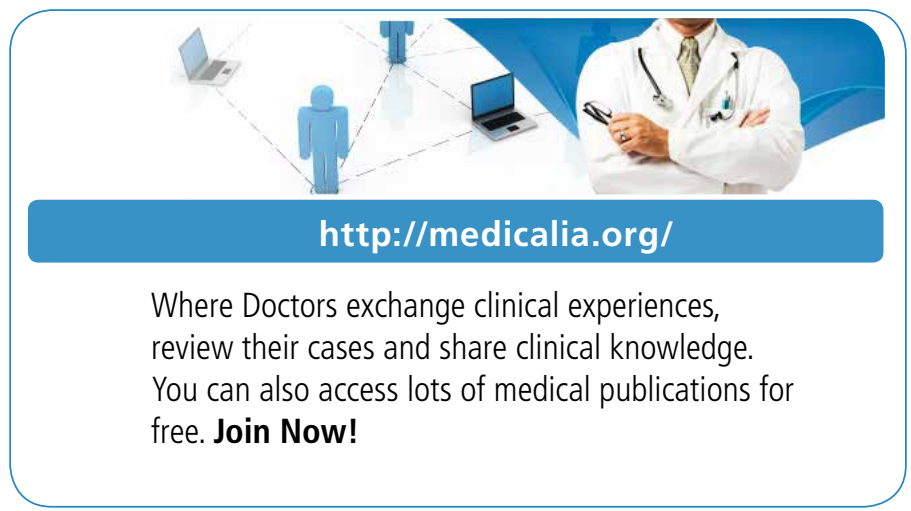

\section{Publish with iMedPub}

http://www.imed.pub

The Journal is an open access peer-reviewed journal that publishes scientific papers about all aspects of antimicrobials. The journal will publish original research articles, reviews, brief reports and case reports dealing with basic and clinical antibacterial agents, antiviral, antiprotozoals, antituberculuous, antifungal and antihelminthes agents.

All manuscripts must be prepared in English, and are subject to a rigorous and fair peer-review process. Accepted papers will immediately appear online.

The journal aims to advance the knowledge, attitude and the research of chemotherapy in the Arabic world in cooperation with international, national scientific and public societies as well as research centers with similar aims and objectives. 